\title{
Effect of osmotic dehydration on the drying kinetics and quality of cashew apple
}

\author{
Patricia Moreira Azoubel, ${ }^{1 *}$ Ânoar Abbas El-Aouar, ${ }^{2}$ Renata Valeriano Tonon, ${ }^{3}$ Louise Emy Kurozawa, ${ }^{3}$ Graziella \\ Colato Antonio, ${ }^{4}$ Fernanda Elizabeth Xidieh Murr ${ }^{3}$ \& Kil Jin Park ${ }^{4}$ \\ 1 Embrapa Semi-Árido, BR 428, km 152, P.O. Box 23, ZIP 56302-970, Petrolina, PE, Brazil \\ 2 Departamento de Tecnologia Química e de Alimentos, Centro de Tecnologia, Universidade Federal da Paraíba, Cidade Universitária, ZIP 58059- \\ 900, João Pessoa, PB, Brazil \\ 3 Departamento de Engenharia de Alimentos, Faculdade de Engenharia de Alimentos, Universidade Estadual de Campinas, P.O. Box 6121, \\ ZIP 13083-970, Campinas, SP, Brazil \\ 4 Faculdade de Engenharia Agrícola, Universidade Estadual de Campinas, P.O. Box 6121, ZIP 13083-862, Campinas, SP, Brazil
}

(Received 19 November 2007; Accepted in revised form 30 May 2008)

Summary The effect of different osmotic pretreatments on cashew apple drying kinetics and product quality were investigated. The osmotic pretreatment was carried out in an incubator at constant temperature and agitation. The drying process was conducted in a fixed bed dryer at different temperatures and constant air velocity. Experimental data were fitted successfully using the Page and the two-term exponential models for dried fresh and pretreated fruit, respectively. It was found that drying rates of osmosed fruits decreased owing to the presence of infused solutes. Evaluation of the final product was performed by means of ascorbic acid content, water activity and sensorial test. The osmotic pretreated samples showed the highest vitamin $\mathrm{C}$ losses and the lowest water activity. The samples pretreated in sucrose solution had the highest acceptance.

Keywords Cashews, drying, kinetics, osmotic dehydration, quality.

\section{Introduction}

The seasonal nature of the production of the perishable cashew apple, the poor storeability and the lack of information on an appropriate processing technology are the reasons hindering the full utilisation of the fruit (Bidaisee \& Badrie, 2001).

Air drying is an ancient process used to preserve foods in which the solid to be dried is exposed to a continuously flowing hot stream of air where moisture evaporates. Although air drying offers dehydrated products that can have an extended life of a year, the quality of a conventionally dried product is usually drastically reduced from that of the original foodstuff (Ratti, 2001).

Several predrying treatments are commonly used in order to minimise adverse changes occurring during drying. Osmotic dehydration is a viable process for partial removal of water from cellular materials, such as fruits and vegetables, without a phase change that reduces the physical, chemical and biological changes during drying at higher temperatures (Kowalska \& Lenart, 2001). It is based on placing foods in a

*Correspondent: Fax: + 55873862 1744;

e-mail: pazoubel@cpatsa.embrapa.br hypertonic solution. As this solution has a higher osmotic pressure, and hence, lower water activity, a driving force for water removal arises between solution and food, while the natural cell acts as a 'semipermeable' membrane. As this membrane is only partially selective, there is always some leakage of solute from the solution into the food and from the fruit into the solution (Lerici et al., 1985). However, the effectiveness of the osmotic behaviour is highly dependent on the osmotic agents utilised (McMinn \& Magee, 1999). Various osmotic agents, such as sucrose, glucose, fructose, corn syrup and sodium chloride, have been used for osmotic dehydration. Generally, sugar solutions are used for fruits (Vijayanand et al., 1995).

Many researchers have investigated the influence of osmotic dehydration prior to conventional drying on the moisture transport characteristics (Islam \& Flink, 1982; Mazza, 1983; Sankat et al., 1996; Nieto et al., 1998). However, in recent years, there has been an increased interest in the investigation of the physical characteristics of fruits after osmotic pretreatment and drying (Mandala et al., 2005).

The objective of this work was to study osmotic dehydration in combination with drying of cashew apple and to evaluate the influence of pretreatment in relation 
to the solution type on the drying kinetics, physicochemical characteristics and sensorial properties of the dried cashew apple.

\section{Material and methods}

\section{Raw material}

Fresh cashew apples (Anacardium occidentale L.) were obtained from a local market (Campinas, Brazil). The fruits were sorted visually for size and maturity level (soluble solids content from 10 to $12^{\circ} \mathrm{Brix}$ ). The nuts were separated manually and the cashew apple was cut into $0.5-\mathrm{cm}$ thick slices using a cutter designed for this purpose. The average slice diameter was $5 \mathrm{~cm}$.

\section{Osmotic pretreatment}

The osmotic dehydration was based in a previous work (Azoubel \& Murr, 2003), in which two different 52\% (w/w) solutions were used: one containing sucrose and the other corn syrup solids (MOR-REX ${ }^{\circledR} 1940$; Corn Products, Brazil). The slices of cashew apple, previously weighed and identified, were placed in $600 \mathrm{~mL}$ beakers containing the osmotic solutions. A fruit/solution ratio of 1:10 was used. The samples were placed in an incubator (Tecnal, TE 421; Tecnal, Piracicaba, SP, Brazil), maintained at $34{ }^{\circ} \mathrm{C}$ and agitation at 80 r.p.m. After $165 \mathrm{~min}$ of experiment, samples were taken out from the osmotic medium, lightly rinsed to remove any excess of sugar solution, drained and then placed on a preweighed drying tray in order to proceed to the drying process.

\section{Drying}

Drying experiments were carried out in a continuous flow fixed bed dryer at constant air velocity of $2.1 \mathrm{~m} \mathrm{~s}^{-1}$ and at three air temperatures $\left(50,60\right.$ and $\left.70^{\circ} \mathrm{C}\right)$. The dryer system consisted of vertical air flow through trays and was arranged as a closed circuit. To maintain constant air condition, only one tray was used with a single layer of sample on it (approximately $60 \mathrm{~g}$ ). For the air heating, three electric resistances were used (two of $1600 \mathrm{~W}$ and one of $800 \mathrm{~W}$ ), which could work independently, controlled by a digital thermostat. A thermal-hygrometer (TESTO, model 635; Testo, Lenzkirch, Germany) was used to measure the dry bulb temperature and the drying air humidity. The air velocity was monitored by an anemometer (AIRFLOW, model LCS 6000; TSI, Buckinghamshire, UK).

Samples had average initial moisture content (wet basis) of $85.7 \%$ for fresh, $69.7 \%$ for sucrose pretreated and $79.7 \%$ for corn syrup pretreated, which was gravimetrically measured using a vacuum oven at $70{ }^{\circ} \mathrm{C}$ for $24 \mathrm{~h}$. Sample moisture content during the air-drying process was gravimetrically determined from the sample initial moisture content (before air-drying process). Sample weight was measured using a semi-analytical balance. Weighing intervals of $15 \mathrm{~min}$ were used during the first hour of processing, $30 \mathrm{~min}$ for the next $2 \mathrm{~h}$ and then $1 \mathrm{~h}$ until the dynamic equilibrium between the sample moisture content and drying air humidity was reached, when the sample weight became constant.

The drying data were fitted with six semi-theoretical thin-layer drying models (Table 1), where $a, b, c, k, k_{0}, k_{1}$ and $n$ are the empirical constants in drying models; $t$ is the drying time, s; MR is the moisture ratio, defined as:

$$
\frac{\bar{X}-X_{e}}{X_{0}-X_{e}}
$$

where $\bar{X}$ is the average moisture content at time $t, \mathrm{~kg}$ $\mathrm{H}_{2} \mathrm{O}$ per kg dry matter; $X_{e}$ is the equilibrium moisture content, $\mathrm{kg} \mathrm{H}_{2} \mathrm{O}$ per $\mathrm{kg}$ dry matter; $X_{O}$ is the initial moisture content, $\mathrm{kg} \mathrm{H}_{2} \mathrm{O}$ per kg dry matter.

The modelling was characterised by the mean relative deviation module $E$ (eqn 2) and the determination coefficient $R^{2}$.

$$
E(\%)=\frac{1}{N} \sum_{i=1}^{N}\left|\frac{V_{e}-V_{p}}{V_{e}}\right| \times 100
$$

where $N$ is the number of experimental data, $V_{e}$ is the experimental value and $V_{p}$ is the calculated value (Lomauro et al., 1985).

\section{Determination of water activity}

The water activity $\left(a_{\mathrm{w}}\right)$ of fresh and dried cashew apple was evaluated at $25^{\circ} \mathrm{C}$ using a water activity meter (Decagon, model 3TE; Decagon, Pullman, WA, USA). Determinations were made on triplicate and the results were reported as an average (error less than $0.5 \%$ ).

\section{Determination of ascorbic acid (AA) content}

The AA content was determined by the method described by Ranganna (1977), which is based on the

Table 1 Thin-layer models used for mathematical determination of

\begin{tabular}{|c|c|c|}
\hline Model & Equation & Reference \\
\hline $\begin{array}{l}\text { Single } \\
\text { exponential }\end{array}$ & $\mathrm{MR}=\exp (-k t)$ & Abe \& Afzal (1997) \\
\hline Page & $M R=\exp \left(-k t^{v}\right)$ & Page (1949) \\
\hline $\begin{array}{l}\text { Henderson } \\
\text { and Pabis }\end{array}$ & $\mathrm{MR}=a \exp (-k t)$ & $\begin{array}{l}\text { Henderson \& Pabis } \\
\text { (1961) }\end{array}$ \\
\hline Logarithmic & $\mathrm{MR}=a \exp (-k t)+c$ & Yaldiz et al. (2001) \\
\hline $\begin{array}{l}\text { Two-term } \\
\text { exponential }\end{array}$ & $\mathrm{MR}=a \exp \left(-k_{0} t\right)+b \exp \left(-k_{1} t\right)$ & $\begin{array}{l}\text { Ozdemir \& Devres } \\
\text { (1999) }\end{array}$ \\
\hline $\begin{array}{l}\text { Wang and } \\
\text { Singh }\end{array}$ & $\mathrm{MR}=1+a t+b t^{2}$ & Wang \& Singh (1978) \\
\hline
\end{tabular}
drying of cashew apple 
reduction of 2,6-dichlorophenol indophenol by AA. Determinations were made on triplicate and the results were reported as an average (error less than $2 \%$ ).

\section{Sensorial analysis}

Cashew apple with and without osmotic pretreatment, dried at $60{ }^{\circ} \mathrm{C}$, was evaluated by 30 non-trained panelists for appearance, colour, taste and aroma on a nine-point hedonic scale $(1=$ 'disliked extremely'; 9 =' 'liked extremely'). Samples were randomly coded with three-digit numbers and their order of presentation was completely randomised for each panelist. Partitioned booths with fluorescent lighting were used for evaluation and these were located in Sensory Evaluation Laboratory of the Faculty of Food Engineering, State University of Campinas (Campinas, Brazil).

A two-way analysis of variance (ANOVA) was used to test the effects of processing pretreatments on the sensory attributes of dried cashew apple. Tukey's test was used to separate the means of the quality attributes by treatments at $P \leq 0.05$.

\section{Results and discussions}

\section{Drying kinetics}

For comparison reasons, the dimensionless moisture content was calculated (up to the dynamic equilibrium point) and its change during drying is presented in Fig. 1. As expected, air temperature affected drying curves, decreasing the drying time of samples.

The statistical analysis values of the models with $E$ around $10 \%$ are summarised in Table 2. The two-term exponential gave good $R^{2}$ values $(>0.99)$ and calculated mean relative deviation ranging from 0.24 to 9.28 , except for the condition of drying the fresh cashew apple at $70^{\circ} \mathrm{C}$, where the Page equation gave the best fit. Similar result was obtained by Doymaz (2004), in which the empirical two-term exponential model gave the best
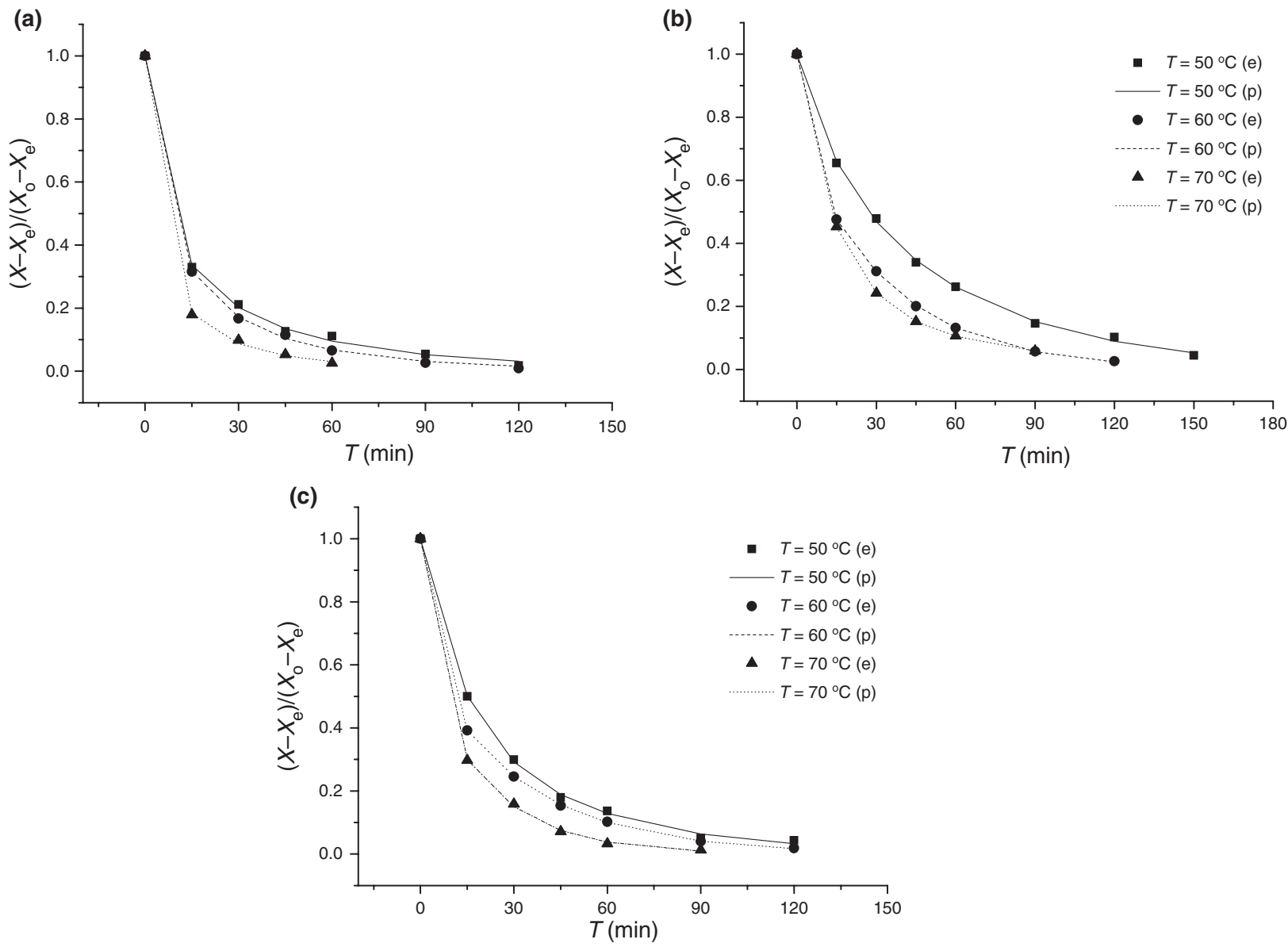

Figure 1 Experimental (e) and predicted (p) drying curves for: (a) fresh (Page model); (b) sucrose osmosed (two-term exponential model); and (c) corn syrup osmosed (two-term exponential model) cashew apple. 
Table 2 Statistical results for thin-layer models with $E$ close to $10 \%$

\begin{tabular}{|c|c|c|c|}
\hline \multicolumn{4}{|l|}{$T=50^{\circ} \mathrm{C}$} \\
\hline Sample & Model & $\begin{array}{l}\text { Model } \\
\text { parameters }\end{array}$ & $E(\%)$ \\
\hline \multirow[t]{4}{*}{ Fresh } & Two-term exponential & $a=0.60$ & 10.27 \\
\hline & & $k_{\mathrm{o}}=0.17$ & \\
\hline & & $b=0.40$ & \\
\hline & & $k_{1}=0.02$ & \\
\hline \multirow[t]{9}{*}{ Sucrose osmosed } & Page & $k=0.04$ & 5.15 \\
\hline & & $v=0.84$ & \\
\hline & Logarithmic & $a=0.94$ & 10.13 \\
\hline & & $k=0.03$ & \\
\hline & & $c=0.05$ & \\
\hline & Two-term exponential & $a=0.25$ & 4.82 \\
\hline & & $k_{\mathrm{o}}=0.07$ & \\
\hline & & $b=0.74$ & \\
\hline & & $k_{1}=0.18$ & \\
\hline \multirow[t]{6}{*}{ Corn syrup osmosed } & Page & $k=0.08$ & 9.27 \\
\hline & & $v=0.78$ & \\
\hline & Two-term exponential & $a=0.54$ & 9.28 \\
\hline & & $k_{\mathrm{o}}=0.08$ & \\
\hline & & $b=0.46$ & \\
\hline & & $k_{1}=0.02$ & \\
\hline \multicolumn{4}{|l|}{$T=60^{\circ} \mathrm{C}$} \\
\hline Sample & Model & $\begin{array}{l}\text { Model } \\
\text { parameters }\end{array}$ & $E(\%)$ \\
\hline \multirow[t]{4}{*}{ Fresh } & Two-term exponential & $a=0.41$ & 5.76 \\
\hline & & $k_{\mathrm{o}}=0.03$ & \\
\hline & & $b=0.59$ & \\
\hline & & $k_{1}=0.16$ & \\
\hline \multirow[t]{6}{*}{ Sucrose osmosed } & Page & $k=0.10$ & 7.56 \\
\hline & & $v=0.74$ & \\
\hline & Two-term exponential & $a=0.73$ & 1.67 \\
\hline & & $k_{\mathrm{o}}=0.03$ & \\
\hline & & $b=0.27$ & \\
\hline & & $k_{1}=0.38$ & \\
\hline \multirow[t]{4}{*}{ Corn syrup osmosed } & Two-term exponential & $a=0.60$ & 2.34 \\
\hline & & $k_{\mathrm{o}}=0.03$ & \\
\hline & & $b=0.40$ & \\
\hline & & $k_{1}=0.24$ & \\
\hline \multicolumn{4}{|l|}{$T=70^{\circ} \mathrm{C}$} \\
\hline Sample & Model & $\begin{array}{l}\text { Model } \\
\text { parameters }\end{array}$ & $E(\%)$ \\
\hline \multirow[t]{2}{*}{ Fresh } & Page & $k=0.40$ & 7.85 \\
\hline & & $v=1.60$ & \\
\hline \multirow[t]{9}{*}{ Sucrose osmosed } & Page & $k=0.11$ & 6.46 \\
\hline & & $v=0.75$ & \\
\hline & Logarithmic & $a=0.93$ & 7.76 \\
\hline & & $k=0.06$ & \\
\hline & & $c=0.07$ & \\
\hline & Two-term exponential & $a=0.27$ & 0.25 \\
\hline & & $k_{\mathrm{o}}=0.02$ & \\
\hline & & $b=0.73$ & \\
\hline & & $k_{1}=0.07$ & \\
\hline
\end{tabular}

Table 2 (Continued)

\begin{tabular}{llll}
\hline $\boldsymbol{T}=\mathbf{7 0}{ }^{\circ} \mathbf{C}$ & & & \\
\hline \multirow{2}{*}{ Sample } & Model & $\begin{array}{l}\text { Model } \\
\text { parameters }\end{array}$ & $\boldsymbol{E}(\%)$ \\
\hline Corn syrup osmosed & Page & $k=0.18$ & 10.92 \\
& & $v=0.70$ & \\
& Two-term exponential & $a=0.60$ & 9.17 \\
& & $k_{\mathrm{o}}=0.05$ & \\
& & $b=0.40$ & \\
& & $k_{1}=1.82$ & \\
\hline
\end{tabular}

fit to the untreated plums. Plots of the experimental and predicted moisture ratios with drying time are represented in Fig. 1.

Figures 2 and 3 show the drying rates as a function of moisture content, where these rates were obtained from experimental values of the moisture with drying time. The physical and chemical changes in the fruit slices during osmosis caused differences in these rates. The sucrose pretreated samples showed the lower rates. Moisture is bound within the solid matrix in many ways (capillaries, physico-chemical bonding to the solid constituents). Hence, the observed differences in drying rates may be related to the solute uptake that occurs in the osmotic process (solids gain was around 6\% for sucrose and $2 \%$ for corn syrup osmosed cashew apple), which resulted in an increased internal resistance to mass transfer, as observed by Rahman \& Lamb (1991) for pineapple and by Karathanos et al. (1995) and Mandala et al. (2005) for apple.

\section{Water activity and AA content}

As it is well known, the stability and safety of foods does improve if water activity $\left(a_{\mathrm{w}}\right)$ of the product decreases. The $a_{\mathrm{w}}$ of foods influences the multiplication, metabolic activity, resistance and survival of the organisms present (Leistner et al., 1981).

The reduction of $a_{\mathrm{w}}$ to about 0.93 would be enough to suppress the growth of most pathogenic bacteria (Chirife \& Favetto, 1992) with the exception of Staphylococcus aureus, which may grow aerobically at $a_{\mathrm{w}}$ values down to 0.86. Most mould and yeast strains are inhibited between 0.88 and 0.80 , although some osmophilic yeast strains can still grow down to 0.6 (Iglesias \& Chirife, 1982).

The osmotic pretreatment was more efficient in reducing $a_{\mathrm{w}}$ (Table 3 ) as a considerable amount of water was removed during osmosis and an incorporation of sugars occurred. The sample without pretreatment and dried at lower temperature $\left(50^{\circ} \mathrm{C}\right)$ did not lower $a_{\mathrm{w}}$ to a safe value. 

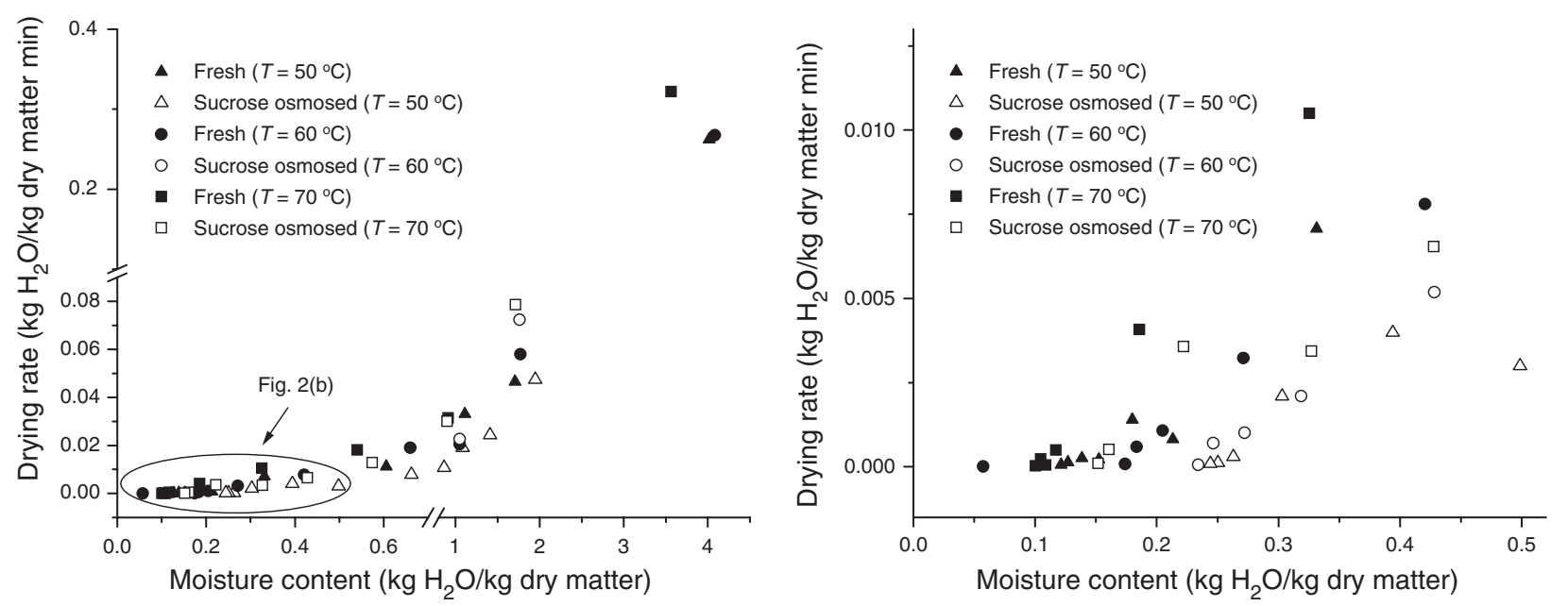

Figure 2 Drying rate curves for fresh and sucrose osmosed cashew apple.
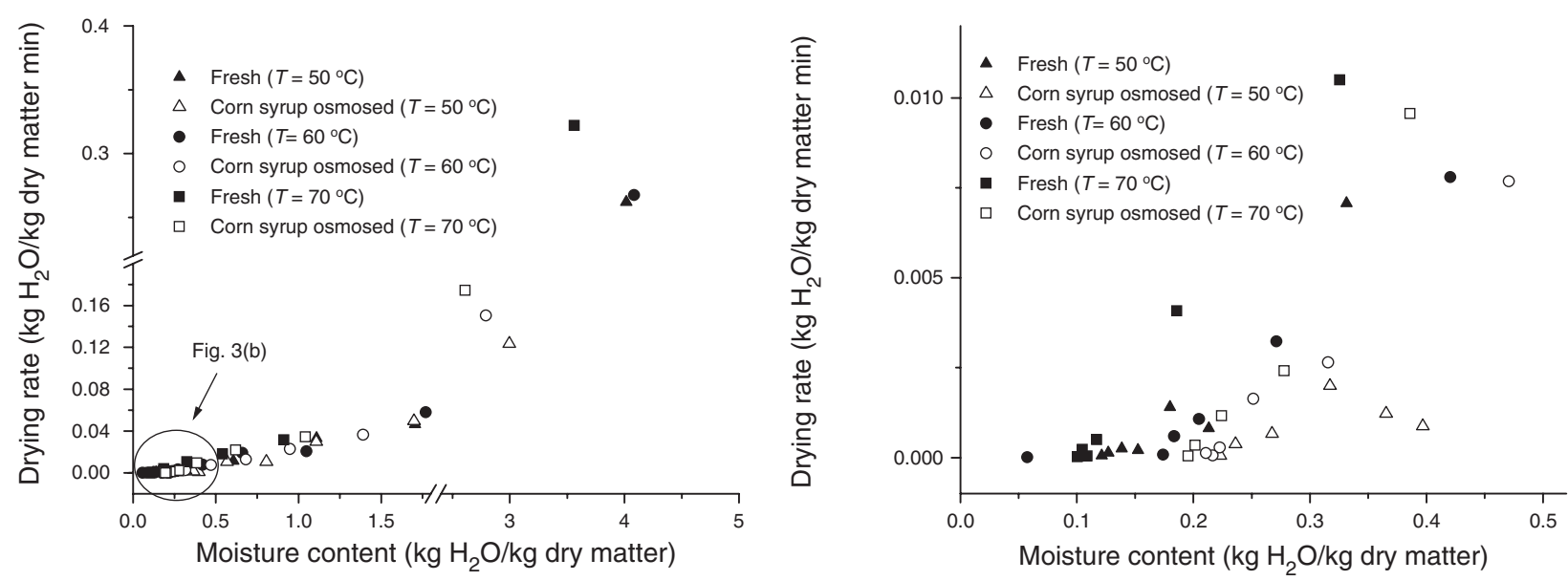

Figure 3 Drying rate curves for fresh and corn syrup osmosed cashew apple.

Ascorbic acid was determined in dried cashew apple (Table 3). All processes resulted in vitamin C (AA) losses. Higher temperatures gave higher losses and the pretreatment was not efficient to protect the samples from oxidations during drying, as the samples submitted to osmotic dehydration presented the lowest AA content. This behaviour may be attributed to the leaching of vitamin $\mathrm{C}$ from the product to the osmotic solution and the chemical degradation during subsequent drying. A similar result was found by Islam \& Flink (1982), Jayaraman et al. (1990) and Azoubel \& Murr (1999), in the drying of potato, cauliflower and cherry tomato, respectively, with and without osmotic dehydration. Islam \& Flink (1982) also reported that, although any dehydration process resulted in vitamin $\mathrm{C}$ losses, the losses appear to be less than that which could occur during warehouse storage of fresh potato over 5 months. Thus, dried or osmosed dried products represent potential improvements in vitamin $\mathrm{C}$ levels for stored potato product.

\section{Sensory evaluation}

The sensory evaluation was performed with the samples dried at $60^{\circ} \mathrm{C}$, as at $50^{\circ} \mathrm{C}$, the untreated sample did not present a safe $a_{\mathrm{w}}$ value, and at $70{ }^{\circ} \mathrm{C}$, the vitamin $\mathrm{C}$ losses were higher, as discussed earlier.

The score attributes of the cashew apple dried at $60{ }^{\circ} \mathrm{C}$ are shown in Table 4. Products pretreated in sucrose solution had the highest test scores, except for 
Table 3 Water activity $\left(a_{\mathrm{w}}\right)$ and ascorbic acid (AA) content of dried cashew apple

\begin{tabular}{llll}
\hline Sample & $\boldsymbol{T}\left({ }^{\circ} \mathbf{C}\right)$ & $\boldsymbol{a}_{\mathbf{w}}$ & AA (mg per $\mathbf{1 0 0} \mathbf{~ g})$ \\
\hline Fresh & 50 & $0.718 \pm 0.001^{\mathrm{aA}}$ & $72.67 \pm 0.49^{\mathrm{aA}}$ \\
& 60 & $0.545 \pm<0.000^{\mathrm{bA}}$ & $57.77 \pm 1.35^{\mathrm{bA}}$ \\
& 70 & $0.442 \pm 0.002^{\mathrm{CA}}$ & $49.92 \pm 1.35^{\mathrm{cA}}$ \\
Sucrose osmosed & 50 & $0.474 \pm 0.002^{\mathrm{aB}}$ & $59.05 \pm 1.01^{\mathrm{aB}}$ \\
& 60 & $0.440 \pm 0.001^{\mathrm{bB}}$ & $51.52 \pm 0.42^{\mathrm{bB}}$ \\
Corn syrup osmosed & 50 & $0.370 \pm 0.010^{\mathrm{cB}}$ & $39.98 \pm 1.06^{\mathrm{cB}}$ \\
& 60 & $0.476 \pm 0.001^{\mathrm{aB}}$ & $59.11 \pm 0.55^{\mathrm{aB}}$ \\
& 70 & $0.482 \pm<0.000^{\mathrm{bC}}$ & $48.45 \pm 1.36^{\mathrm{bC}}$ \\
& $70<0.000^{\mathrm{cA}}$ & $34.77 \pm 2.09^{\mathrm{cC}}$ \\
\hline
\end{tabular}

Natural cashew apple: $a_{\mathrm{w}}=0.989$ and $\mathrm{AA}=204.78 \mathrm{mg}$ per $100 \mathrm{~g}$. Values represent means of three determinations \pm standard deviations. Mean separation by the Tukey test $(n=3)$. Different letters are considered significantly different at the $5 \%$ level $(P<0.05)$. Lowercase letters represent the response variation with drying temperature. Capital letters represent the response variation with osmotic agent.

Table 4 Sensory scores for quality attributes of dried cashew apple

\begin{tabular}{lllll}
\hline Sample & Appearance & Aroma & Taste & Texture \\
\hline Fresh & $6.81^{\mathrm{a}}$ & $6.54^{\mathrm{a}}$ & $6.04^{\mathrm{a}}$ & $5.92^{\mathrm{ab}}$ \\
Sucrose osmosed & $7.42^{\mathrm{a}}$ & $6.00^{\mathrm{a}}$ & $7.38^{\mathrm{b}}$ & $6.38^{\mathrm{a}}$ \\
Corn syrup osmosed & $7.00^{\mathrm{a}}$ & $5.88^{\mathrm{a}}$ & $6.62^{\mathrm{ab}}$ & $5.42^{\mathrm{b}}$ \\
\hline
\end{tabular}

Any means in the same columns with the same letters are not significantly different $(P>0.05)$.

aroma. The samples pretreated in corn syrup had test scores closer to the untreated samples. As observed by Azoubel \& Murr (2003), samples immersed in sucrose solution had a solid gain around $6 \%$, while those immersed in corn syrup had a solid gain around $2 \%$, what explained the similar behaviour to the untreated samples.

There were no significant differences $(95 \%$ level) between samples for appearance and aroma. However, although Torreggiani (1993) reported that osmotic dehydration is effective in minimising heat damage to aroma, the samples with no pretreatment step had the highest score for this attribute. The samples osmotically pretreated had the highest scores for appearance, in which the sugar uptake, owing to the protective action of the saccharides, increases the stability of pigments during processing, as observed by Kim (1990).

Regarding taste, there was no significant difference (95\% level) among pretreated samples. However, there was a significant difference between the samples osmotically pretreated in sucrose solution and those not pretreated. Nassu et al. (2001) observed that differences in the acceptance of fresh and sucrose osmosed cashew apple may be attributed to a reduction of typical astringency caused by tannins in fresh fruit, when a complex with tannins and added sugar is formed and by degradation of tannins caused during heat treatment. In addition, some of the acids are removed from the fruit during osmotic dehydration; hence a blender and sweeter product than ordinary dried fruits is obtained (Ponting et al., 1966).

For texture, there was a significant difference $(95 \%$ level) only between the samples osmotically pretreated. Islam \& Flink (1982) reported that differences in texture may arise from differences in rate and extent of drying, together with the effect of infused solute. Lenart (1996) also reported that osmotic dehydration before drying has a protective effect on the structure of the dried material, which is characterised by a flexible and fluffy structure.

\section{Conclusions}

Osmosed samples had lower drying rates owing to the initial solid content, requiring more time to reach the same final moisture content as fresh cashew apple. Sucrose pretreated samples had the lowest values owing to the higher solute uptake during osmotic dehydration.

Page's model showed a good fit to the experimental data of dried fresh fruit, and the calculated average relative errors were up to $15 \%$. For the pretreated samples, the two-term exponential model had the best fit, with calculated average relative errors lower than $10 \%$.

The osmotic pretreatment was more efficient in reducing $a_{\mathrm{w}}$; however, it was not efficient to protect samples from AA losses. The sucrose osmosed samples had the highest acceptance.

\section{Acknowledgments}

The authors gratefully acknowledge the financial support of FAPESP (The State of São Paulo Research Foundation). They also thank Corn Products Brazil for supplying the corn syrup solids.

\section{References}

Abe, T. \& Afzal, T.M. (1997). Thin-layer in infrared radiation drying of rough rice. Journal of Agricultural Engineering Research, 67, 289297.

Azoubel, P.M. \& Murr, F.E.X. (1999). Effect of osmotic dehydration on the drying kinetics of cherry tomato. In: Proceedings of the Sixth Conference on Food Engineering. Pp. 471-476. Dallas, USA.

Azoubel, P.M. \& Murr, F.E.X. (2003). Optimization of osmotic dehydration of cashew apple (Anacardium Occidentale L.) in sugar solutions. Food Science and Technology International, 9, 427-433.

Bidaisee, G. \& Badrie, N. (2001). Osmotic dehydration of cashew apple (Anacardium occidentale L.): quality evaluation of candied cashew apples. International Journal of Food Science and Techono$\log y, 36,71-78$.

Chirife, J. \& Favetto, G.J. (1992). Some physical-chemical basis of food preservation by combined methods. Food Research International, 25, 5, 389-396. 
Doymaz, I. (2004). Effect of dipping treatment on air drying of plums. Journal of Food Engineering, 64, 465-470.

Henderson, S.M. \& Pabis, S. (1961). Grain drying theory I: temperature effect on drying coefficient. Journal of Agricultural Engineering Research, 6, 169-174.

Iglesias, H.A. \& Chirife, J. (1982). Handbook of Food Isotherms. 347 p. New York: Academic Press.

Islam, M.N. \& Flink, L.N. (1982). Dehydration of potato II - osmotic concentration and its effect on air drying behavior. Journal of Food Technology, 17, 387-403.

Jayaraman, K.S., das Gupta, D.K. \& Babu Rao, N. (1990). Effect of pretreatment with salt and sucrose on the quality and stability of dehydrated cauliflower. International Journal of Food Science and Technology, 25, 47-60.

Karathanos, V.T., Kostaropoulos, A.E. \& Saravacos, G.D. (1995). Air drying of osmotically dehydrated fruits. Drying Technology, 13, $1503-1521$.

Kim, M.H. (1990). Osmotic concentration of apples and its effect on browning reaction during air dehydration. Journal of the Korean Society of Food Nutrition, 19, 121-126.

Kowalska, H. \& Lenart, A. (2001). Mass exchange during osmotic pretreatment of vegetables. Journal of Food Engineering, 49, 137-140.

Leistner, L., Rödel, W. \& Krispien, K. (1981). Microbiology of meat and meat products in high and intermediate moisture ranges. In: Water Activity: Influences on Food Quality. P. 855. New York: Academic Press.

Lenart, A. (1996). Osmo-convective drying of fruits and vegetables: technology and application. Drying Technology, 14, 391-413.

Lerici, C.R., Pinnavaia, G., Dalla Rosa, M. \& Bartolucci, L. (1985). Osmotic dehydration of fruits: influence of osmotic agents on drying behavior and product quality. Journal of Food Science, 50, 1217-1220.

Lomauro, C.J., Bakshi, A.S. \& Labuza, T.P. (1985). Evaluation of food moisture sorption isotherm equations. Part I: fruit, vegetable and meat products. Lebensmittel-Wissenschaft and Technologies, $\mathbf{1 8}$, $112-122$.

Mandala, I.G., Anagnostaras, E.F. \& Oikonomou, C.K. (2005). Influence of osmotic dehydration conditions on apple air-drying kinetics and their quality characteristics. Journal of Food Engineering, 69, 307-316.

Mazza, G. (1983). Dehydration of carrots. Effects of pre-drying treatments on moisture transport and product quality. Journal of Food Technology, 18, 113-123.
McMinn, W.A.M. \& Magee, T.R.A. (1999). Studies on the effect of surfactant, blanching and osmotic pretreatments on the convective drying of potatoes. Journal of Food Process Engineering, 22, 419433.

Nassu, R.T., Lima, J.R. \& Souza Filho, M. de S.M. (2001). Consumer's acceptance of fresh and combined methods processed melon, mango and cashew apple. Revista Brasileira de Fruticultura, 23, 551-554.

Nieto, A., Salvatori, D., Castro, M.A. \& Alzamora, S.M. (1998). Air drying behavior of apples as affected by blanching and glucose impregnation. Journal of Food Engineering, 36, 63-79.

Ozdemir, M. \& Devres, Y.O. (1999). The thin-layer drying characteristics of hazelnuts during roasting. Journal of Food Engineering, 42, 225-233.

Page, G.E. (1949). Factors Influencing the Maximum of Air Drying Shelled Corn in Thin Layer. Indiana: Purdue University.

Ponting, J.D., Walters, G.G., Forrey, R.R., Jackson, R. \& Stanley, W.L. (1966). Osmotic dehydration of fruits. Food Technology, 20, 125-128.

Rahman, M.D. \& Lamb, J. (1991). Air drying behaviour of fresh and osmotically dehydrated pineapple. Journal of Food Engineering, 14, $163-171$.

Ranganna, S. (1977). Manual of Analysis of Fruit and Vegetables Products. 634 p. New Delhi: Mc-Graw Hill Publishing Company.

Ratti, C. (2001). Hot and freeze-drying of high-value foods: a review. Journal of Food Engineering, 49, 311-319.

Sankat, C.K., Castaigne, F. \& Maharaj, R. (1996). The air drying behaviour of fresh and osmotically dehydrated banana slices. International Journal of Food Science and Technology, 51, 123135.

Torreggiani, D. (1993). Osmotic dehydration in fruit and vegetable processing. Food Research International, 26, 59-68.

Vijayanand, P., Chand, N. \& Eipeson, W.E. (1995). Optimization of osmotic dehydration of cauliflower. Journal of Food Processing and Preservation, 19, 229-242.

Wang, C.Y. \& Singh, R.P. (1978). Use of variable equilibrium moisture content in modeling rice drying, ASAE Paper, 78-6505, ASAE, St. Joseph-MI.

Yaldiz, O., Ertekin, C. \& Uzun, H.I. (2001). Mathematical modeling of thin-layer solar drying of sultana grapes. Energy, 26, 457-465. 